\title{
Decolorization of Tartrazine azo dye by Sulphidogenesis Process and the effect of $\mathrm{pH}$
}

\author{
Kuldeep Kulshrestha ${ }^{1}$, Arka Kiran Choudhury ${ }^{2}$, P.C. Sabumon ${ }^{3}$ \\ School of Civil Engineering \\ Vellore Institute of Technology (VIT), Chennai-600127, India \\ E-mail: pcsabumon@vit.ac.in
}

\begin{abstract}
This study aims to investigate Tartrazine as a model azo dye with a concentration of $100 \mathrm{mg} / \mathrm{l}$ for decolorisation by sulphidogenesis process in a sequencing batch reactor (SBR). SBR was operated at $30 \pm 2{ }^{\circ} \mathrm{C}$ room temperature and initial cycle time of 7 days which has later been reduced to 1-2 days. SBR was operated at COD/Sulphate ratio of 1 . SBR did well in terms of reducing color, COD and sulphates. Maximum color, COD and sulphate removal were $84 \%, 74 \%$ and $88 \%$ respectively. Activated sludge could be used as seed biomass for the development of the process. In the later part of our study, we tried to optimize the best $\mathrm{pH}$ to remove color by setting the six reactors with varying $\mathrm{pH}$. The results show that optimal $\mathrm{pH}$ for decolorization is between 8 and 9 and effective color removal (87-92\%) could be achieved in a day. It is also seen that alkaline $\mathrm{pH}$ is more favoured than acidic $\mathrm{pH}$ for decolorization of Tartrazine. The results of this study indicate an economical and ecofriendly technique for decolorization of Tartrazine at $100 \mathrm{mg} / \mathrm{l}$.
\end{abstract}

Key words: Sulphidogenesis, Sulphate reducing bacteria (SRB), Sequencing batch reactor (SBR), Acclimatized sludge, Anoxic

\section{INTRODUCTION}

Azo dyes are aromatic compounds that consist of $-\mathrm{N}=\mathrm{N}$ - groups. They are the major class of synthetic dyes used in various industries, namely, textile, food coloring, cosmetics and paper printing, and among these textile industries largest user of dyes. All the dye does not stick to the fabric and depends on the dye used, the loss could vary from $2 \%$ for basic dyes to as high as $50 \%$ [1] for reactive dyes and upon their release into the environment, they pose a severe threat. These dyes and their by-products are carcinogenic in nature and are reported as more threatening wastewaters when compared to other industrial effluents, even their low concentrations equal to " $1 \mathrm{mg} / \mathrm{l}$ " can make surface water looks colorful, which is not good aesthetically and also that color interrupts the sunlight which inhibit photosynthesis process thus affects the aquatic life [2]. Color removal from wastewaters has been a big challenge over the last years. There are many physical and chemical processes to treat the colored effluents, but their operation cost is quite high, while the biological process offers a lower cost and an eco-friendly technique [3].

Generally, mineralization of azo dye requires both anaerobic and aerobic biological processes [4]. Though the anaerobic process removes color and COD and formation of aromatic amines, these are not mineralized in anaerobic phase and are considered toxic in nature [5]. This tends to develop a 2 stage sequencing anaerobic-aerobic batch process; reduced products are oxidized in the second phase. The role of sulphidogenesis process may be effective for decolorisation of azodyes since sulphate concentration can be in the range $1700-2700 \mathrm{mg} / \mathrm{l}$ in the textile dyeing effluents [6]. Ozdemir, et. al. [7] investigated the performance of azo dye reduction in a sulphidogenic anaerobic reactor over a period of 400 days. The reactor consists of 4 sections, in which three of them are anoxic and the fourth section is aerated. The dye used in this study was C. I Reactive Violet 5 and azo dye concentrations varied between 20 and $200 \mathrm{mg} / \mathrm{l}$, Throughout the study the $\mathrm{COD} / \mathrm{SO}_{4}{ }^{2-}$ ratio was less than 1 ensuring sulphidogenic conditions. The results in this study showed high COD removal efficiencies and high dye removal efficiencies. Also, as the $\mathrm{COD} / \mathrm{SO}_{4}{ }^{2-}$ ratio was increased, there was increased sulfate removal efficiencies from $81 \%$ to $91 \%$. The maximum COD removal, Sulfate removal and color removal efficiencies were $98 \%, 98 \%$ and $93 \%$ respectively.

So far, different dyes with different anaerobic reactors for textile wastewaters have been used; namely, fluidized bed reactors [8], upflow sludge 
blanket reactor and packed bed reactors [9], anaerobic baffled reactor [7]. However, Tartrazine has not been examined under sequencing batch reactor (SBR) with sulfate reducing bacteria (SRB), so this study focuses on decolorization of Tartrazine dye sulphate reducing bacteria in SBR process and the effect of $\mathrm{pH}$ on decolorisation was investigated.

\section{MATERIALS AND METHODS}

\section{A. Nutrient media}

The following nutrients in $\mathrm{g} / \mathrm{l}$ were used for SBR feed: Yeast, 1; $\mathrm{NaHCO}_{3}, 2.1 ; \mathrm{NH}_{4} \mathrm{Cl}$, $0.11965 ; \mathrm{K}_{2} \mathrm{HPO}_{4}, 0.035 ; \mathrm{MgCl}_{2}, 0.2 ; \mathrm{H}_{3} \mathrm{BO} 3$, 0.0005; $\mathrm{ZnCl}_{2}, 0.0005 ;\left(\mathrm{NH}_{4}\right)_{6} \mathrm{Mo}_{7} \mathrm{O}_{24} \cdot 4 \mathrm{H}_{2} \mathrm{O}$, $0.0005 ; \mathrm{NiCl}_{2} .6 \mathrm{H} 2 \mathrm{O}, 0.0005 ; \mathrm{AlCl}_{3} \cdot 6 \mathrm{H}_{2} \mathrm{O}$, $0.0005 ; \mathrm{MnCl}_{2} .4 \mathrm{H}_{2} \mathrm{O}, 0.0005 ; \mathrm{CoCl}_{2} \cdot 4 \mathrm{H}_{2} \mathrm{O}$, $0.0005 ; \mathrm{Na}_{2} \mathrm{SeO}_{3} .5 \mathrm{H}_{2} \mathrm{O}, 0.001 ; \mathrm{CuSO}_{4} .5 \mathrm{H}_{2} \mathrm{O}$, 0.0005; $\mathrm{CaCl}_{2}, 0.003 ; \mathrm{FeCl}_{2}, 0.000015$; EDTA, 0.000015 .

\section{B. Electron sources}

Sucrose $(2.5 \mathrm{~g} / \mathrm{l})$ is used as readily degradable carbon source, at the same time it provides electron for the cleavage of azo dye. Tartrazine dye in the concentration of $100 \mathrm{mg} / \mathrm{l}$ is used for colored wastewater in each cycle of SBR operation. The electron acceptor in the experiment was sulphate (added as $\mathrm{Na}_{2} \mathrm{SO}_{4}, 3.7$ $\mathrm{g} / 1)$.

\section{Reactor setup and experimental design}

To start the SBR to check the feasibility of decolorisation of Tartrazine, we took the available acclimatized sludge in the Environmental Engineering laboratory which was used for decolorisation of Methyl orange by sulphidogenesis process. Batch incubations were conducted at $30 \pm 2^{\circ} \mathrm{C}$ in glass serum bottles of "150 ml" capacity sealed with neoprene rubber septum and secured with aluminium caps. We took three serum bottles; 1 control with just dye and nutrient media while 2 bottles of nutrient media, dye of $100 \mathrm{mg} / \mathrm{l}$ concentration and sludge $(25 \mathrm{ml})$ in each bottle. The $\mathrm{COD} / \mathrm{SO}_{4}{ }^{2-}$ ratio of the nutrient media was kept as one to promote the sulphidogensis by SRB [10]. These sealed bottles were then kept on an orbital shaker at $120 \pm 2 \mathrm{rpm}$ (Scigenics Biotech, India) with initial cycle time of 7 days. The cycle time reduced in subsequent cycles as and when the decolorization happened. The time for filling, settling and decanting was $\leq$ $1 \mathrm{~h}$ in each cycle.
After seeing the feasibility of decolorization, an enrichment of activated sludge which was collected from VIT Chennai wastewater treatment plant with MLVSS value of $1.344 \mathrm{~g} / \mathrm{L}$ was done in a 51 SBR (Plastic cargo) to decolorize $100 \mathrm{mg} / \mathrm{l}$ of Tartrazine with $1000-1200 \mathrm{ml}$ of sludge and rest of the reactor filled with nutrient media at $\mathrm{COD} / \mathrm{SO}_{4}{ }^{2-}$ ratio equal to one. The nutrient media was replaced every 6 days interval and on acclimatization the cycle time reduced to 2 days. The time for filling, settling and decanting was $\leq 2 \mathrm{~h}$ in each cycle. After 10 cycles of acclimatization the sludge was drawn to study the effect of $\mathrm{pH}$ in decolorization. For this 6 serum bottles with $30 \mathrm{ml}$ of acclimatized sludge (MLVSS $=3.479 \mathrm{~g} / \mathrm{l}$ ) in each bottle was taken and then each bottle was filled with Tartrazine dye of concentration $100 \mathrm{mg} / \mathrm{l}$ in nutrient media. The nutrient media with dye was pre-adjusted with varying $\mathrm{pH}$ of 5, 6, 7, 8 and 9 with $1 \mathrm{~N} \mathrm{HCl}$ and $1 \mathrm{~N} \mathrm{NaOH}$ and sixth bottle was used as a control with just acclimatized sludge and dye concentration of $100 \mathrm{mg} / \mathrm{l}$ and $\mathrm{pH}$ $7.6 \pm 0.1$. These sealed bottles were then kept on an orbital shaker at $120 \pm 2 \mathrm{rpm}$.

\section{ANALYTICAL PROCEDURES}

Color absorbance, sulphate, sulfide, soluble $\mathrm{COD}$ and $\mathrm{pH}$ were measured after each cycle. Oxidation Reduction Potential (ORP) was also measured weekly to ensure the anoxic conditions in the reactors. Samples were centrifuged for 10 minutes before analyzing absorbance, COD and sulphates while $\mathrm{pH}$ and sulfide were measured with MLSS samples without centrifugation.

Color was measured using UV-VIS Spectrophotometer, and absorbance was measured at the peak absorption wavelength in visible range $\left(\lambda_{\max }=425 \mathrm{~nm}\right)$ against a baseline defined by triple distilled water. All physicochemical parameters were measured according to the standard procedures [11]. ORP was measured with an ORP electrode (platinum with silver/silver chloride as electrode, $3 \mathrm{M} \mathrm{KCl}$ ) connected to digital meter. $\mathrm{pH}$ was measured using $\mathrm{pH}$ of 2-point $\mathrm{pH}$ meter. Sulphate was measured as absorbance at " $420 \mathrm{~nm}$ " wavelength followed by experimental derived curve $\left(\mathrm{R}^{2}=0.994\right)$. Sulfide analysis is done at the end of each cycle by the iodometric method mentioned in APHA 1998 [11]. All the tests and values were taken in duplicates and average values are reported. 


\section{RESULTS AND DISCUSSION}

\section{A. Color removal}

The sequencing batch reactors were initially operated with a cycle time of 7 days and after each cycle, fresh nutrient media with dye concentration of $100 \mathrm{mg} / \mathrm{l}$ was added for subsequent process to induce the biomass for more acclimatization. After a certain number of cycles, it has been observed that level of sludge in serum bottles has increased which shows there was growth of adapted sludge. The temperature and $\mathrm{pH}$ values measured during the cycles in reactors were " $28 \pm 1^{\circ} \mathrm{C}$ " and initial $\mathrm{pH}$ of " $7.6 \pm 0.1$ " and at the end of cycles the recorded $\mathrm{pH}$ was " $6.3 \pm 0.1$ ". This drop in $\mathrm{pH}$ could be because of volatile acid formation in anoxic conditions and these acids are being utilized by SRB to reduce sulphates to sulfides. The percentage of color removal in the reactors at the end of each cycle is presented in Fig. 1. From the results, it is clear that on acclimatization of the sludge in sulfidogenic environment decolorization of the dye improved and it reached from $69 \%$ in 7 days to $84 \%$ in 2 days cycle time. These results prove that decolorization of Tartrazine can be achieved in sulphidogenic environment easily and has an application potential. There are probably at least two mechanisms for the decoloration of azo dyes in bacterial systems: (i) direct electron transfer to azo dyes as terminal electron acceptors via enzymes during bacterial catabolism, connected to ATP-generation (energy conservation), and (ii) a gratuitous reduction of azo dyes by the end products of bacterial catabolism, not linked to ATP-generation; in this case it is the $\mathrm{H}_{2} \mathrm{~S}$ formed as a result of sulphidogenesis .

Fig. 2 shows the effect of initial $\mathrm{pH}$ in the decolorization of dye. The results show that optimal pH for decolorization is between 8 and 9 and effective color removal (87-92\%) could be achieved in a day. It is also seen that alkaline $\mathrm{pH}$ is more favoured than acidic $\mathrm{pH}$ for decolorization of Tartrazine. The results show that the decolorisation took long hours if the $\mathrm{pH}$ is not maintained in the optimal range. Chang et al. [11] found that the dye reduction rate increased nearly 2.5 -fold as the $\mathrm{pH}$ was raised from 5.0 to 7.0 , while the rate became insensitive to $\mathrm{pH}$ in the range of 7.0-9.5. Similar results are obtained in this study.

\section{B. COD oxidation and Sulphate reduction}

The percentage removal of COD after the end of each cycle in the reactors during the feasibility study is given in Fig. 3. In each cycle $\mathrm{COD} /$ sulphate ratio is maintained at one with each approximately equal to $2500 \mathrm{mg} / \mathrm{l}$. The removal of COD has increased after each cycle and reached almost $73 \%$ at the end of fifth cycle. The electrons released from electron donor are transferred to azo dye and sulphate, resulting in color removal, sulphate reduction, and, therefore, decreased COD amount.

The percentage removal of COD in SBRs used for studying the effect of $\mathrm{pH}$ is shown in Fig.4. The results show that the highest reduction of COD was $81 \%$ when the initial $\mathrm{pH}$ was adjusted to 8.0. Also, it is to be noted that the trend of COD removal is in agreement with the percentage removal of color, indicating that there is a mineralization of the dye as a result of sulphidogenesis process. The control reactor with initial $\mathrm{pH}(7.6 \pm 0.1)$ showed only $66 \%$ removal of COD and took more time to degrade compared to more alkaline pHs 8 and 9. Therefore, the results support that alkaline pHs remove more color and COD.

Fig. 5 shows the percentage removal of sulphates in SBRs used for studying the effect of $\mathrm{pH}$. The results show that in alkaline $\mathrm{pHs}$ the percentage of sulphate removal is efficient and highest removal of $79 \%$ was obtained at $\mathrm{pH} 9$. From the trends in removals of color (Fig.2), COD (Fig.4) and Sulphate (Fig.5), it is evident that the decolorization of Tartrazine associated with the sulphidogenesis process.

\section{Sulphide production}

As the bacteria enriched in the reactor are sulphate reducing type, the sulphate is being converted to sulfide; this was evident from the rotten egg smell sensed while opening the serum bottles at the end of each cycle for analysis of the parameters. This is due to more percentage sulfides as free $\mathrm{H}_{2} \mathrm{~S}$ due to the acidic $\mathrm{pH}(6.3 \pm 0.1)$. At this acidic $\mathrm{pH}, 90 \%$ of the sulfide is in gaseous form, which tends to escape on opening the reactors, while the remaining is in a soluble form that was analysed and in the range of 150-220 mg/l.

\section{D.ORP measurements}

At the end of each cycle, ORP in the serum bottles was measured. The values were always 


\section{FIGURES}

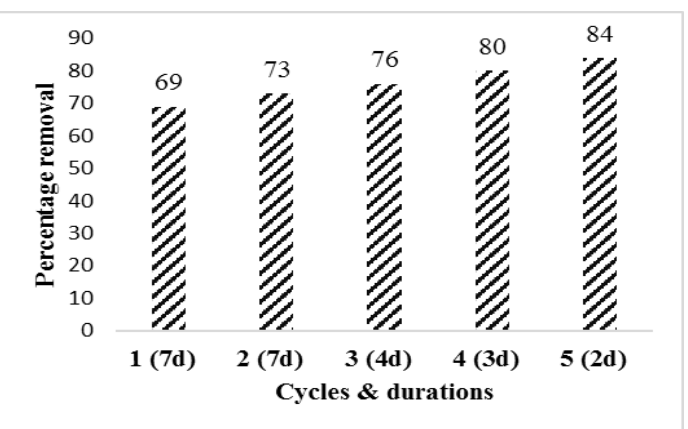

Fig.1 Percentage color removal after each cycle

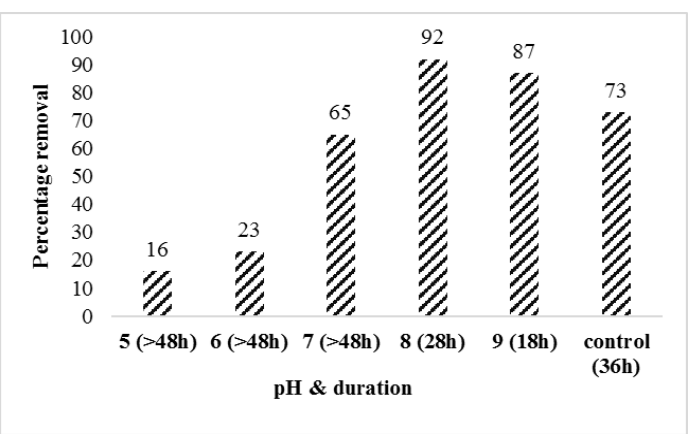

Fig.2 Percentage color removal at each pH

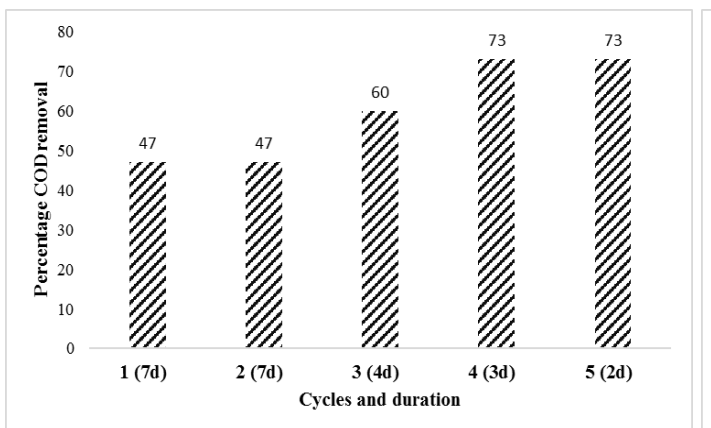

Fig. 3 Percentage removal of COD after each cycle

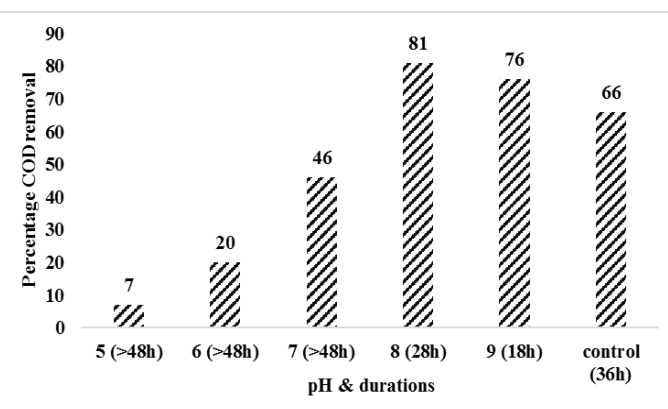

Fig. 4 Percentage removal of COD at each $\mathrm{pH}$

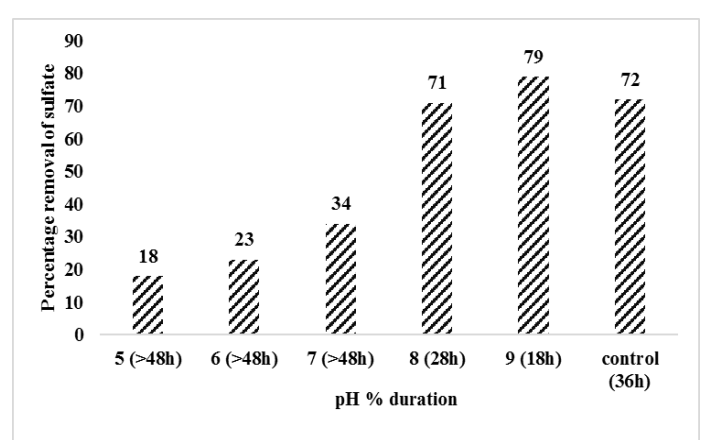

Fig. 5 Percentage removal of sulphate at each pH

\section{Conclusion}

The results of this study show that activated sludge could be used as an effective seed sludge for developing sulphidogenesis process for decolorization of Tartrazine dye at $100 \mathrm{mg} / \mathrm{l}$. The effective dye removal could be achieved in SBR operation in 2 days on acclimatization of biomass. The time for decolorization could be reduced to around 24 hours at an optimal $\mathrm{pH}$ between 8 and 9 . The results of this study indicate an economical and ecofriendly technique for decolorization of Tartrazine at $100 \mathrm{mg} / \mathrm{l}$.

\section{References}

1. Correia, V. M., Stephenson, T., \& Judd, S. J. (1994). Characterisation of textile wastewaters-a review. Environmental technology, 15(10), 917-929.

2. Saini, R. D. (2017). Textile organic dyes: polluting effects and elimination methods 
from textile waste water. Int J Chem Eng Res, 9(1), 121-136.

3. Van der Zee, F. P., \& Villaverde, S. (2005). Combined anaerobic-aerobic treatment of azo dyes - a short review of bioreactor studies. Water research, 39(8), 1425-1440.

4. Hu, T. L. (1998). Degradation of azo dye RP2B by Pseudomonas luteola. Water Science and Technology, 38(4-5), 299-306.

5. Carliell, C. M., Barclay, S. J., Shaw, C., Wheatley, A. D., \& Buckley, C. A. (1998). The effect of salts used in textile dyeing on microbial decolourisation of a reactive azo dye. Environmental technology,19(11), 1133-1137.

6. Bisschops, I., \& Spanjers, H. (2003). Literature review on textile wastewater characterisation. Environmental technology, 24(11), 1399-1411.

7. Işı1k, M., \& Sponza, D. T. (2008). Anaerobic/aerobic treatment of a simulated textile wastewater. Separation and purification technology, 60(1), 64-72.

8. Işık, M., \& Sponza, D. T. (2008). Anaerobic/aerobic treatment of a simulated textile wastewater. Separation and purification technology, 60(1), 64-72.

9. Apha, A. (1998). Wef. Standard methods for the examination of water and wastewater, 21, 1378.

10. Pearce, C. I., Lloyd, J. R., \& Guthrie, J. T. (2003). The removal of colour from textile wastewater using whole bacterial cells: a review. Dyes and pigments, 58(3), 179-196.

11. Chang, J. S., Chou, C., Lin, Y. C., Lin, P. J., Ho, J. Y., \& Hu, T. L. (2001). Kinetic characteristics of bacterial azo-dye decolorization by Pseudomonas luteola. Water research, 35(12), 2841-2850. 